\title{
First evidence of rooting lycopsids preserved as imprints and trace fossils from the Silves Sandstone (Upper Triassic, eastern Algarve, South Portugal)
}

\author{
Eduardo J. MAYORAL ${ }^{1^{*}}$, Ana SANTOS ${ }^{1} \&$ J. Bienvenido DIEZ ${ }^{2}$
}

\author{
${ }^{1}$ Departamento de Ciencias de la Tierra, Facultad de Ciencias Experimentales, Universidad de Huelva, Campus de El Carmen, \\ Avda. 3 de Marzo, s/n, 21071 Huelva, Spain; mayoral@uhu.es; asantos@dgyp.uhu.es \\ ${ }^{2}$ Departamento de Geociencias Marinas y Ordenación del Territorio, Universidad de Vigo, Campus Lagoas-Marcosende, 36200 \\ Vigo, Spain; jbdiez@uvigo.es \\ * Corresponding author
}

Mayoral, E.J., Santos, A. \& Diez, J.B. 2016. First evidence of rooting lycopsids preserved as imprints and trace fossils from the Silves Sandstone (Upper Triassic, eastern Algarve, South Portugal). [Primeras evidencias de enraizamiento de licopsidas conservadas como impresiones y pistas fósiles en las Areniscas de Silves (Triásico Superior, Algarve oriental, Sur de Portugal)]. Spanish Journal of Palaeontology, 31 (1), 131-144.

\section{ABSTRACT}

Rooting lycopsids, preserved as imprints on the Upper Triassic Silves Sandstone in the Eastern Algarve region (South Portugal), are recorded for the first time in this area. The Silves Sandstone is composed of the characteristic dark red sandstones and conglomerates of this formation and contains all the studied imprints. These have a quadrate or pseudohexagonal outline corresponding to the departure of roots placed in four to six roughly symmetrical points around the stem bases. Two generations of plants are observed, including the imprints of seedlings. Palaeoenvironmental conditions for the lower unit have been interpreted as a shallow lagoon or stationary bodies of water in a swamplike environment subjected to sporadic current activity. This would have uprooted stems and ripped off the leaves. The upper unit would correspond to a fluvial environment with the establishment of an inundated floodplain with periodic subaerial exposure; this is where root imprints, shallow vertebrate (Rhynchosauroides isp.) and invertebrate trace fossils (Cochlichnus anguineus, Vagorichnus cf. anyao, Palaeophycus tubularis, Taenidium isp., Scolicia isp.), tetrapod footprints and raindrop imprints were recorded.

\section{RESUMEN}

Se han caracterizado por primera vez enraizamientos de licopsidas conservadas como impresiones en las Areniscas de Silves, de edad Triásico Superior, en el Algarve oriental (Sur de Portugal). Esta formación está compuesta por los típicos conglomerados, areniscas y lutitas de la Formación y contiene la totalidad de las impresiones estudiadas. Estas impresiones tienen un perímetro cuadrado a pseudohexagonal que corresponde a la salida de las raíces colocadas grosso modo en cuatro o seis puntos simétricos alrededor de la base del tronco. Se han podido reconocer dos generaciones de plantas, incluyendo las dejadas por las plántulas. Las condiciones paleoambientales deducidas para la unidad inferior corresponden a un lagoon somero o a cuerpos de agua en un medio de características pantanosas, sometido a esporádicas corrientes de agua, que arrancarían los tallos y las hojas de los mismos. La unidad superior se interpreta como un medio fluvial con láminas de agua ocupando llanuras de inundación, que estarían expuestas periódicamente a condiciones subaéreas que facilitaron el asentamiento de las raíces y el registro de pistas someras producidas por vertebrados (Rhynchosauroides isp.) e 
Lycopsids may have colonized these marshy areas in between wet (occasional flash floods) and drier episodes. Uprooting of the stems was probably caused by sudden and strong mass flow produced during intervals of heavy rain.

Keywords: Rooting structures, Lycopsida, trace fossils, Upper Triassic, S Portugal. invertebrados (Cochlichnus anguineus, Vagorichnus cf. anyao, Palaeophycus tubularis, Taenidium isp., Scolicia isp.), así como icnitas de tetrápodos e impresiones de gotas de lluvia. Las licopsidas colonizarían estas áreas pantanosas producidas entre episodios húmedos (flujos de inundación ocasionales) y más secos. El desarraigo de los troncos se produciría como consecuencia de fuertes y repentinos flujos de masa ligados a eventos de lluvias intensas.

Palabras clave: Estructuras de enraizamiento, Lycopsida, pistas fósiles, Triásico Superior, S Portugal.

\section{INTRODUCTION}

Lycopsida had their maximum diversity in the Pennsylvanian, particularly arborescent forms such as Lepidodendron and Sigillaria, that dominated tropical wetlands (Greb et al., 2006; Cleal et al., 2012). Changes to a much drier climate in the Mesozoic (Jenkyns, 2003; Sellwood \& Valdes, 2007; Hermann et al., 2012) gave rise to the appearance, among others, of new forms of arboreous sphenophytes, that were very common during the Triassic and Jurassic. After the worldwide Permian-Triassic extinction event Lycopsida resurfaced as opportunistic plants and diversified quickly from the Middle Triassic, where sphenopsids were abundant too (Gall et al., 1998; Grauvogel-Stamm, 1998, 1999; Willis \& McElwain, 2002; Moisan \& Voigt, 2013). The lycopsid Pleuromeia sternbergii was one of the first plants to proliferate after the biotic crisis occurred at the end of the Permian, characterizing the upper part of the Lower Triassic (Menning, 1995).

In the Upper Triassic deposits of the studied area, remains of Equisetaceae and Neocalamitaceae have been found together with a large number of Pleuromeialike imprints of rooting structures, thus suggesting the existence of fossil lycopsids. Imprints of these plants can be seen in practically all outcrops of the studied unit. Ichnoassemblages have been found in addition to the plant fossils. The trace fossils allow reconstructing the environmental conditions of these deposits.

The aims of this study are twofold: (1) to survey and characterize the rooting lycopsids for the first time in this area in the South of Portugal; and (2) to determine the palaeoenvironmental conditions of the Silves Sandstone.

\section{GEOGRAPHICAL AND GEOLOGICAL SETTING}

The study area is located in the eastern Algarve (South Portugal), in the Mealhas Valley, near Bengado, São Brás de Alportel municipality (Fig. 1).
The studied materials correspond to the Silves Sandstone ("Grés de Silves" sensu Choffat, 1887 or interval AB1 in Palain, 1975), which overlies Carboniferous shale and greywacke unconformably in an E-W fringe of the Algarve region. It has been assigned to the Upper Triassic (?) - Keuper (Rocha, 1976; Lopes, 2014). The lower part is composed of red conglomeratic sandstones and mudstones with finegrained interbedded siltstone and dolomites (not observable in the study area) and, at the top, of red sandstones.

\section{MATERIALS AND METHODS}

About a hundred rooting structures were studied in situ, mostly recorded in red sandstones and conglomerates. Specimens were measured using digital calipers, photographed, and the spatial relationships recorded.

All trace fossils were recorded and analyzed in the field, no specimens were collected.

\subsection{Stratigraphy}

In the study area the Silves Sandstone is composed of conglomerates, sandstones and mudstones, dark red in colour. These materials are exposed continuously along the entire Algarve region. This unit is assigned to the Upper Triassic (Keuper) (Palain, 1975, 1979) as indicated by the presence of Euestheria minuta (von Zieten, 1833) and Pseudoasmussia destombesi Defretin, 1950.

The presence of poorly preserved stegocephalian bones in São Bartolomeu de Messines (to the west of the study area) suggests an Early Triassic age for lutites at the base of the Silves Sandstone (Antunes, 2010).

\subsubsection{Vale das Mealhas}

Here the typical dark red clastic unit is represented. Two sections have been investigated:

Bengado section 1 (Figs 2A, 5a). 


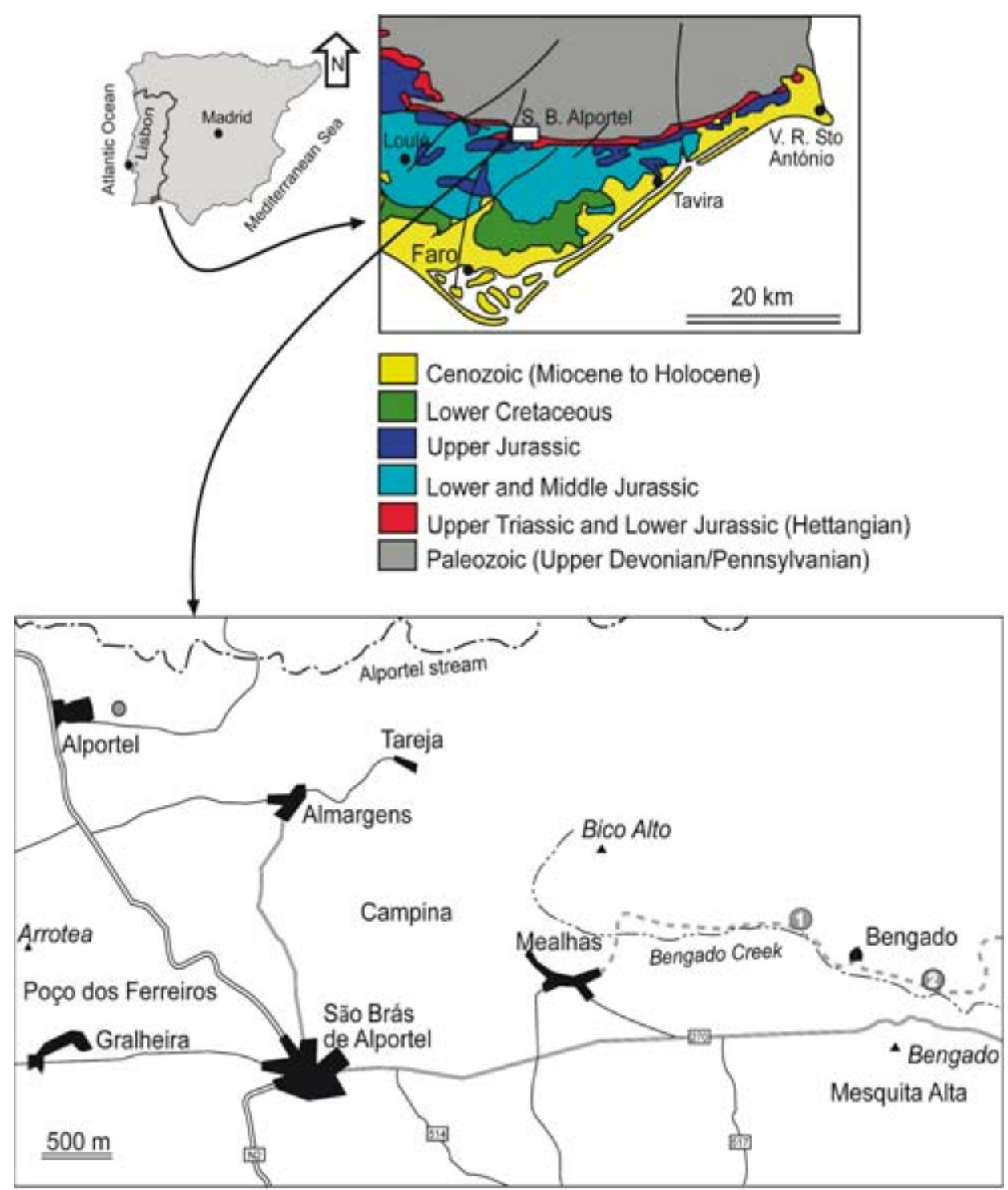

Figure 1. Geological sketch of Algarve Basin (Adapted from Geological Map of Portugal, 1:500 000 SGP, 1992) and location of outcrops at the Bengado sites 1 and 2.
Composed of the following intervals:

1. $12.5 \mathrm{~m}$ of a set formed by red beds, mainly mudstone usually poorly exposed with a sandstone, $20-35 \mathrm{~cm}$ thick, and containing conglomerate intercalations. They commonly show convex top surfaces, sometimes with coarse, pebbly material (subangular to subrounded quarzites) in patches on top. These convex surfaces show small depressions, corresponding to the imprints of small tree bases (Fig. 3A, levels b, c, and d) except in the lower horizon (a) and medium upper part of this set (e). In the latter, sandstones and conglomerates are more frequent and thick (c. $60 \mathrm{~cm}$ ). They show shallow erosive channel forms with low-angle cross bedding and minor bioturbation by roots. Cochlichnus angineus and Palaeophycus tubularis are present in some thin, fine-grained intercalated sandstones.

2. $3.5 \mathrm{~m}$ of wine red sandstones, consisting of 25-50 $\mathrm{cm}$ thick, massive beds, with small unsorted, angular and subangular quarzite pebbles "floating" on the top of each interval. Bioturbation of small roots and Cochlichnus angineus with depressions left, most likely, by small rooting trees are recorded in these surfaces. At the bottom and at the top of these set layers of erosive, apparently channelized, very coarse sandstones and conglomerates appear with imprints of small stem bases (Fig. 3A, levels $\mathrm{f}$ and $\mathrm{h}$ ) and Palaeophycus tubularis. $5 \mathrm{~m}$ of a set composed in the lower half $(3 \mathrm{~m})$ of red mudstones, very poorly exposed, alternating with a thin layer $(20 \mathrm{~cm})$ of red sandstones upper half of set formed by wine red sandstone, very coarse-grained, in channels, with low angle cross-bedding and horizontal lamination at the top. Bioturbation by rooting is apparent in lower levels of this interval.

Beds strike W-E (98 $)$, and dip southwards $\left(42^{\circ}\right)$ (Figs 2A, 3a).

Bengado section 2 (Figs 2B, 4a). 


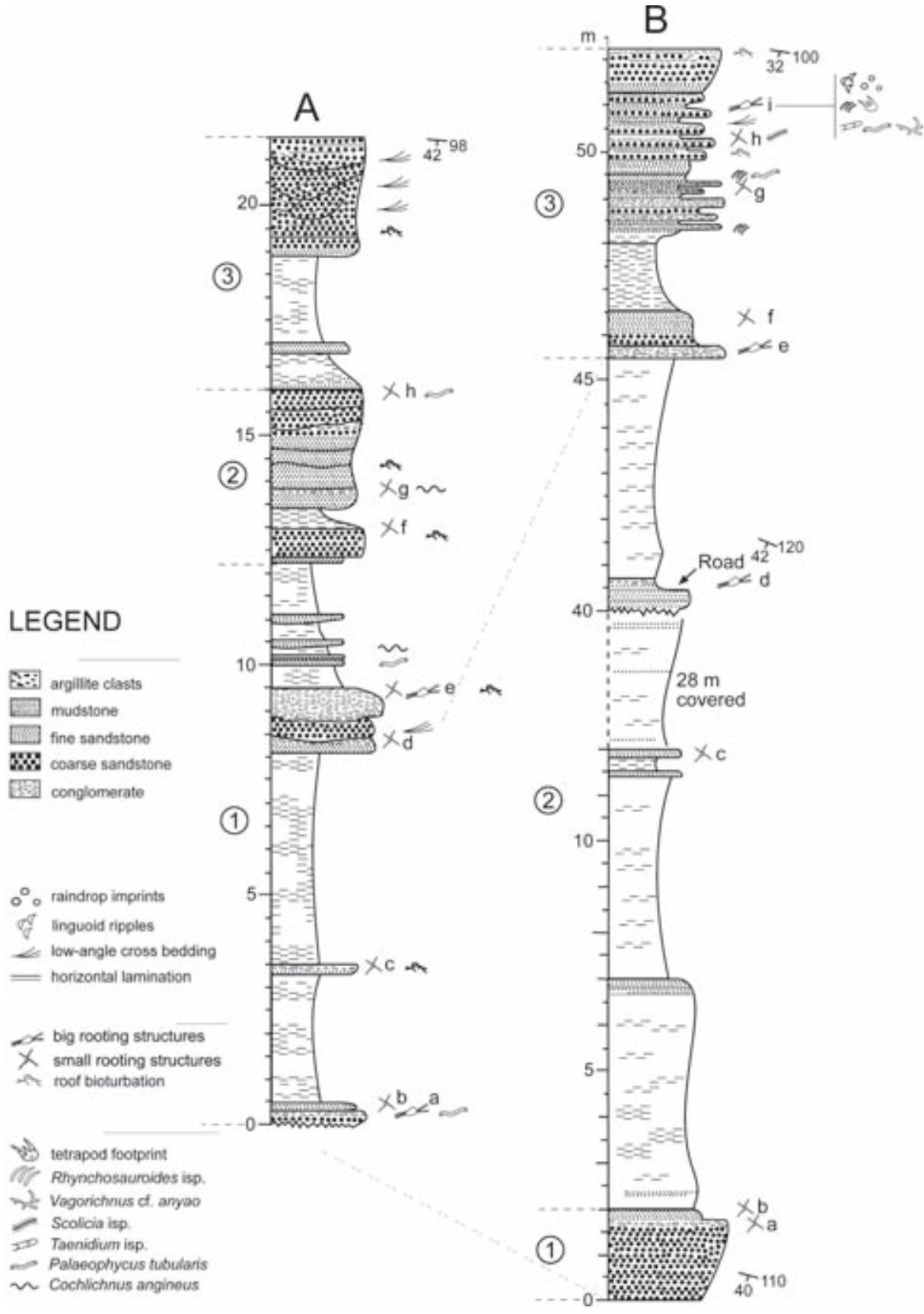

Figure 2. Stratigraphic sections of the Bengado site. A) Section 1. B) Section 2. 1 to 3: lithostratigraphic intervals; a to i: intervals containing rooting structures.

Composed by the following intervals:

1. $2 \mathrm{~m}$ of red coarse sandstone, conglomeratic, with orange-yellowish, subangular quartzite pebbles and finegrained sandstone intercalations at the top, both with imprints of small tree bases (Fig. 2B, levels a and b).

2. $43.5 \mathrm{~m}$ of red mudstone, very poorly exposed with intercalations of fine-grained sandstones with imprints of small roots on the top surfaces (levels $\mathrm{c}$ and d). The $\mathrm{d}$ level shows a good lateral exposure (outcrop on the road) where several generations of different root sizes are visible (Fig. $4 \mathrm{~b})$.
3. $6.5 \mathrm{~m}$ of conglomerates in layers of $15-30 \mathrm{~cm}$ thickness alternating with red coarse sandstones bearing subangular pebbles of quartzite "floating" on the top surfaces and wine-red fine-grained sandstones and mudstones $(1.5 \mathrm{~m})$ at the bottom of this set. Lower conglomerate shows large depressions of rooting trees at the top (Fig. 2B, level e) and in large parts of the sandstone layers, although in this case, the size of rooting imprints is smaller (levels $\mathrm{f}-\mathrm{i}$ ). It is noteworthy that on the top of three sandstone beds of this section Rhynchosauroides isp. have been recorded, additionally the presence of linguoid ripples with imprints of raindrops and abundant bioturbation is recognized 


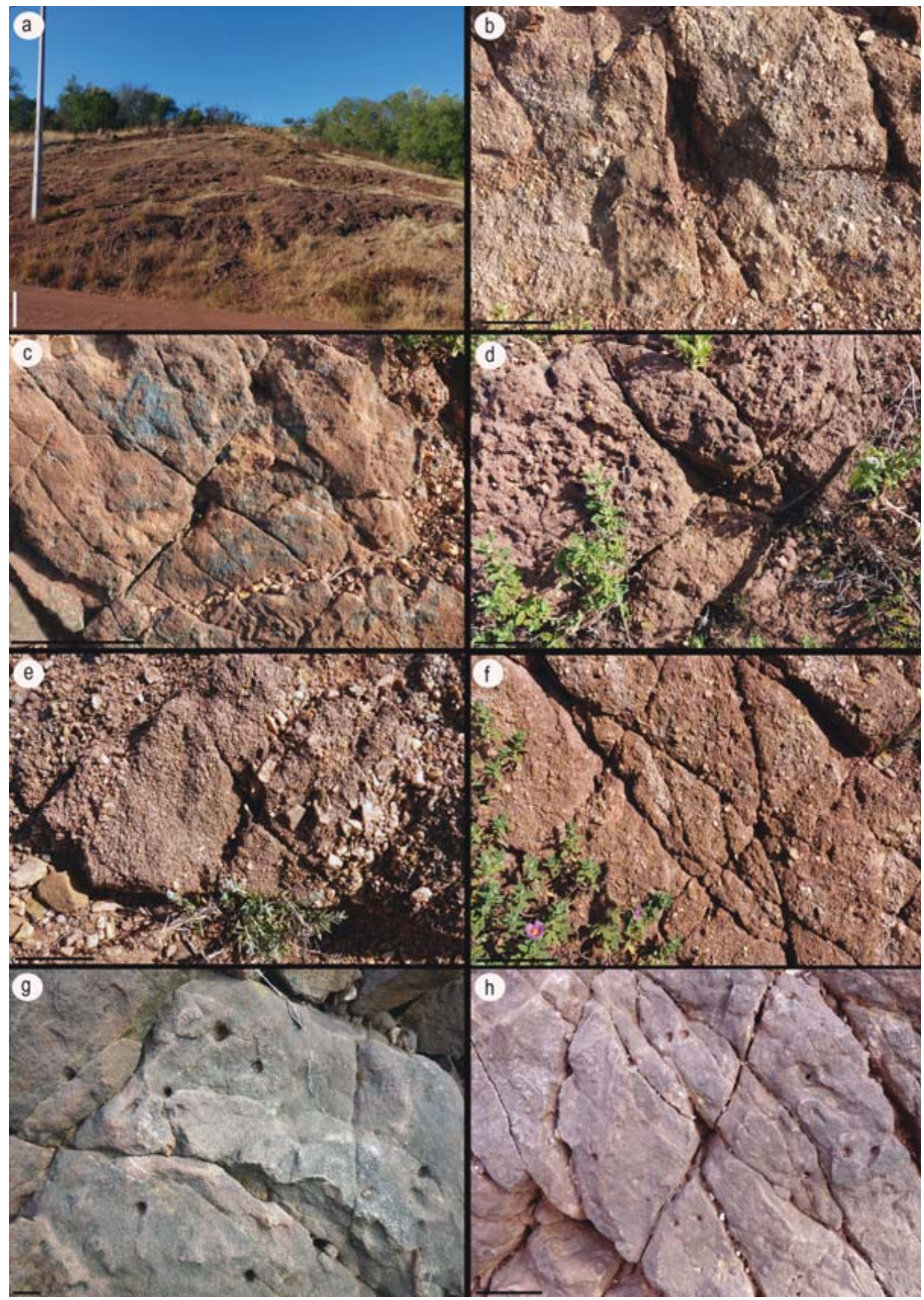

Figure 3. Dark red sandstones and conglomerates of the Silves Sandstone at Bengado section 1. a) General view of the outcrop. Scale bar: $1 \mathrm{~m}$. b) Large imprint of a rooting structure at level a. Scale bar: $15 \mathrm{~cm}$. c-e) Imprints of rooting lycopsids. All figures represent small, isolated specimens at levels b, and e, respectively. Scale bar: (c): $15 \mathrm{~cm}$, (d-e): $5 \mathrm{~cm}$. f) Group of small imprints at level g. Scale bar: $10 \mathrm{~cm}$. Note small angular pebbles floating on the top layer of a density flow deposit (also in Fig. 3e). g) Very young specimens and seedling imprints at level h. Scale bar: $1 \mathrm{~cm}$. h) Isolated small imprints and seedling imprints at level h. Scale bar: $5 \mathrm{~cm}$. 
Table 1. Size of imprints of rooting structures (corresponding to the stem diameter) and the number and rooting length and the separation between them. A) Bengado section 1. B) Bengado section 2. Numbers in brackets: mean value.

\begin{tabular}{|c|c|c|c|c|}
\hline \multicolumn{2}{|c|}{$\begin{array}{l}\text { Central imprint diameter } \\
(\mathrm{cm})\end{array}$} & \multirow{2}{*}{$\begin{array}{c}\begin{array}{c}\text { Number } \\
\text { of Rooting } \\
\text { branches }\end{array} \\
4-6(4)\end{array}$} & \multirow{2}{*}{$\begin{array}{c}\text { Rooting branches length } \\
\text { (cm) } \\
6-36(16) \\
19-58(28) \\
\end{array}$} & \multirow{2}{*}{$\begin{array}{c}\text { Distance between imprints (cm) } \\
18\end{array}$} \\
\hline Level a & 7 & & & \\
\hline Level b & $0.5-3.5(1.7)$ & 4 & $\begin{array}{l}9-28(15,5) \\
5-8.5(7,5)\end{array}$ & $12-14$ \\
\hline Level c & $1-8(3)$ & 4 & 4-15 (10) & 15 \\
\hline Level d & 8 & --- & --- & 90 \\
\hline Level e & 3 & 4 & $\begin{array}{c}9-20(14) \\
5-7(6) \\
\end{array}$ & $\begin{array}{l}84 \\
22 \\
\end{array}$ \\
\hline Level f & 2.5 & 4 & $18-22(20)$ & 17 \\
\hline Level $\mathbf{g}$ & $0.6-34(10)$ & 4-6 (4) & $1.8-34(8.5)$ & $5-28(10)$ \\
\hline Level h & $1.2-5(3)$ & $4-8(6)$ & $\begin{array}{c}7-17(10) \\
34-64(46)\end{array}$ & $\begin{array}{c}0.8-7(3) \\
21\end{array}$ \\
\hline
\end{tabular}

$\mathrm{B}$

\begin{tabular}{|c|c|c|c|c|}
\hline \multicolumn{2}{|c|}{$\begin{array}{l}\text { Central imprint diameter } \\
\text { (cm) }\end{array}$} & \multirow{2}{*}{$\begin{array}{c}\begin{array}{c}\text { Number } \\
\text { of Rooting } \\
\text { branches }\end{array} \\
6 \\
\end{array}$} & \multirow{2}{*}{$\begin{array}{c}\begin{array}{c}\text { Rooting branches length } \\
\text { (cm) }\end{array} \\
13-22(16) \\
\end{array}$} & \multirow{2}{*}{$\begin{array}{c}\text { Distance between imprints (cm) } \\
15\end{array}$} \\
\hline Level a & $8-10$ & & & \\
\hline Level b & 10 & 6 & $17-30(25)$ & 60 \\
\hline Level c & $15-20$ & 6 & $11-20(16)$ & 120 \\
\hline Level d & $4-20(14)$ & $4-8(6)$ & $\begin{array}{l}7-12(8.8) \\
20-34(22)\end{array}$ & $20-80(43)$ \\
\hline Level e & $10-20$ & 4 & 18 & 50 \\
\hline Level f & $4-12(6)$ & $4-8$ & $9-20(13)$ & 19 \\
\hline Level $\mathbf{g}$ & 24 & 8 & $12-20(15)$ & 85 \\
\hline Level h & 40 & 6 & $16-19(18)$ & 40 \\
\hline Level i & $11-17(14)$ & 6 & $\begin{array}{l}18-21(19) \\
50-95(62) \\
\end{array}$ & 80 \\
\hline
\end{tabular}

(Cochlichnus anguineus, Vagorichnus cf. anyao, Palaeophycus tubularis, Taenidium isp. Scolicia isp.), and tetrapod footprints (Figs 7-8).

Beds of this section strike ONO-ESE $\left(100^{\circ}-120^{\circ}\right)$, and dip SSW-wards $\left(32^{\circ}-42^{\circ}\right)$ (Figs $\left.2 \mathrm{~B}, 4 \mathrm{a}-4 \mathrm{~b}\right)$.

\section{RESULTS}

\subsection{Rooting structures}

Most of the top sandstones and conglomerate surfaces of the red unit (Figs 3-4, Bengado sections 1-2) exhibit numerous imprints of rooting structures attributed to the class Lycopsida. Such structures are very common in the Carboniferous and are known as Stigmaria. The degree of preservation of our specimens is not always adequate, and only in a few cases external casts comparable to the typical Paleozoic Stigmaria can be observed, just as described by Wagner \& Diez (2007) for the Pennsylvanian in the Northern Palencia province (NW Spain) or by Wagner \& Mayoral (2007) for the Permian of Valdeviar in Seville province (SW Spain).

Another possible interpretation for these rooting structures would be in relation to the genus of extinct Pleuromeia, a lycopsid plant from the Triassic (GrauvogelStamm \& Lugardon, 2001). Unlike other arborescent lycopsids of the Carboniferous, such as Lepidodendron and Sigillaria, Pleuromeia had a four-lobed bulblike base rather than a branching underground rhizome. 

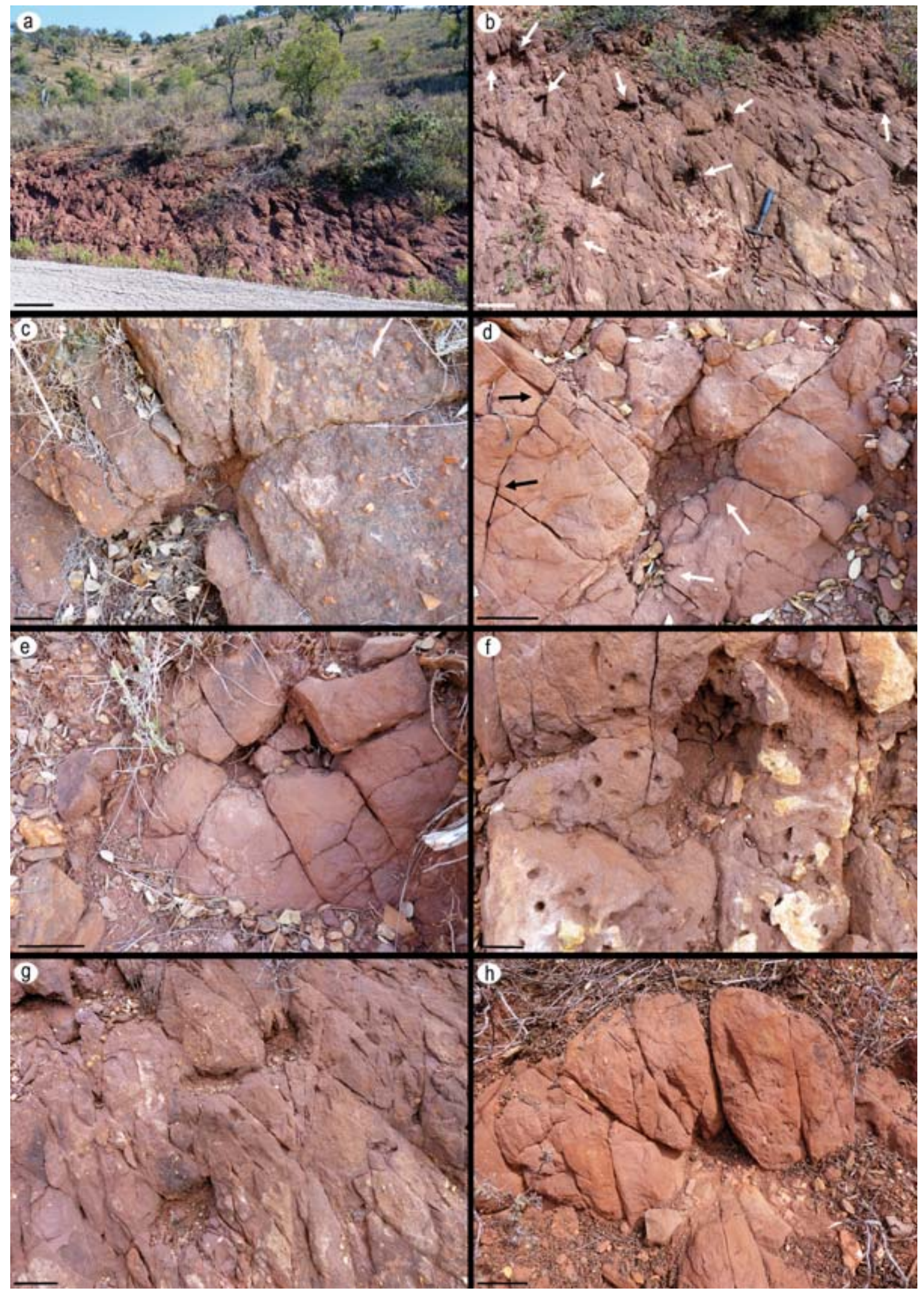

Figure 4. Dark red sandstones and conglomerates of the Silves Sandstone at Bengado section 2. a) General view of the outcrop. Scale bar: $1 \mathrm{~m}$. b) Detail of the surface showing position of the imprint of a large rooting structure (white arrows). Scale bar: $30 \mathrm{~cm}$. c) Isolated small imprint of rooting structure at level a. Scale bar: $5 \mathrm{~cm}$. d) Large (white arrows) and small (black arrows) imprints at level b. Scale bar: $10 \mathrm{~cm}$. e) Group of small imprints at level b. Scale bar: $10 \mathrm{~cm}$. f) Seedling imprints (dark small circles) around a large rooting structure at level d. Scale bar: $5 \mathrm{~cm}$. g) Group of small and large rooting imprints at level d. Scale bar: $15 \mathrm{~cm}$. h) Large imprint at level h. Scale bar: $10 \mathrm{~cm}$. 


\subsubsection{Description}

Imprints belong to relatively deep $(5-15 \mathrm{~cm}$ depth) tree bases with a four-cornered outline corresponding to the departure of roots at four roughly equidistant points around the tree base (Figs 3c-3f, 5a). This arrangement is perfectly observed in younger individuals (imprints with less than $5 \mathrm{~cm}$ in diameter), while in older ones $(>5 \mathrm{~cm}$ in diameter) it is common to observe the presence of 6 or 8 roots, conferring a pseudohexagonal outline to the central imprint (Figs 4c-4h, 5b-5d, 6a-6e).

The roots are very narrow, usually not more than 5 $\mathrm{mm}$ wide and relatively long, to $6-46 \mathrm{~cm}$ on average in the outcrop of section 1 and from 8.8 to $62 \mathrm{~cm}$ in section 2 (Table 1). Only rarely, they are branch into smaller ones, a characteristic exhibited only by a few large specimens (Figs 4g-4h, 5d, 6e-6f).

This appearance clearly differentiates them from the ones described in the Pennsylvanian by Wagner \& Diez (2007), yet they are the same as those observed by Wagner \& Mayoral (2007) in the early Permian of the Cerro de los Pavones section (Valdeviar Basin, Seville, Spain). Although

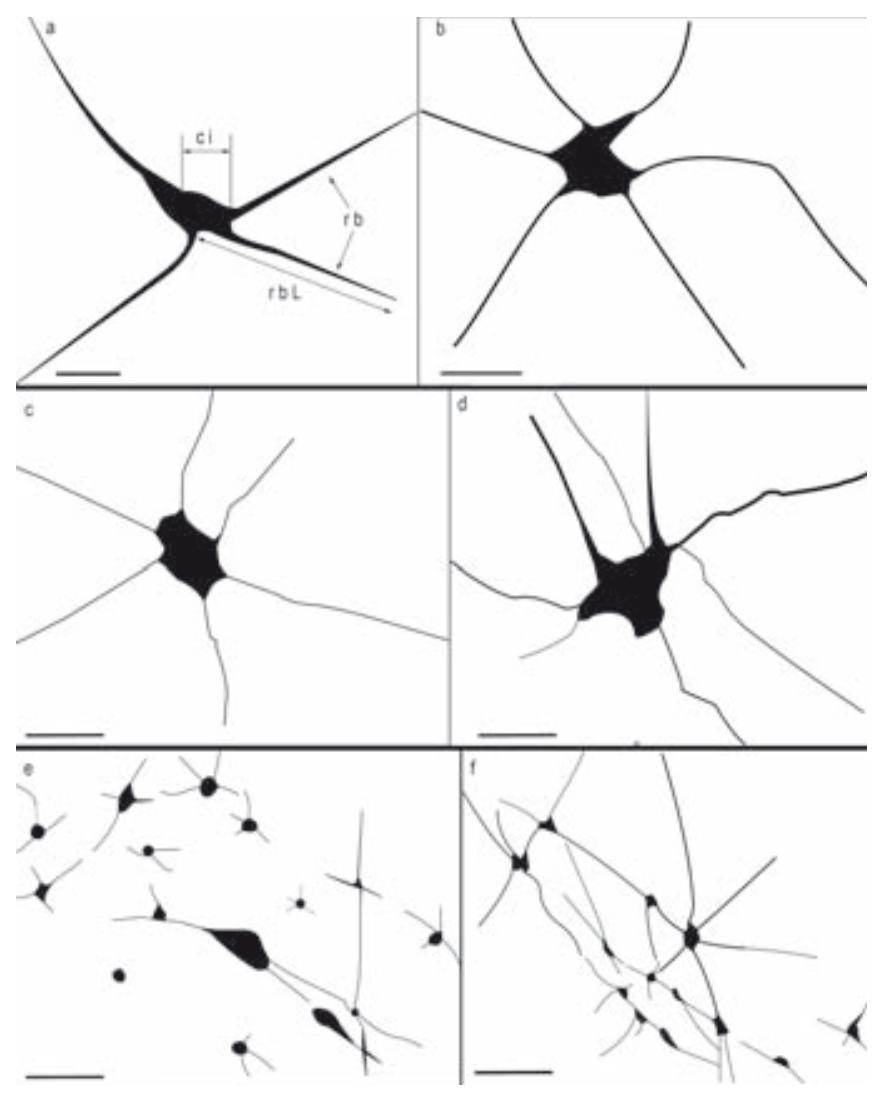

Figure 5. Sketches of small rooting structures at Bengado. a) With four exits of roots, level e, Section 1. c i: central imprint, $r$ b: exits of roots, $r \mathrm{~b}$ L: exits of roots Length. b-c) With six roots, levels b and f, Section 2. d) With eight roots, level a, Section 2. e-g) Groups in levels $\mathrm{h}$ and $\mathrm{g}$ of Section 1. All scale bars: $5 \mathrm{~cm}$. there are two distinct sizes (Table 1), all of them can be considered generally corresponding to small specimens (the mean diameter of the imprints is $11-12 \mathrm{~cm}$ ), which could explain the fact that not multiple rooting branches are observed, as is typical in the Pennsylvanian-Lower Triassic Lycopsida, thus corresponding to a relatively early stage of development.

The extent of the rooting systems was not very large, so that the distance between the trees was quite small, additionally confirming its small size. In the outcrop of section 1, these distances vary from layers to others, from less than 1 to $90 \mathrm{~cm}$, with an average value of about $20 \mathrm{~cm}$. In section 2, these distances are somewhat larger, because the impressions are usually bigger, and vary from 15 to $120 \mathrm{~cm}$, with an approximate average of $60 \mathrm{~cm}$ (Table 1).

The environmental conditions of the ecosystem seem to have been be quite suitable for the initial settlement of these trees, since the space between the largest (first generation) was occupied extensively by the smaller (second generation) (Figs 4g, 6f) resulting in connections and overlaps between rooting bases of different sizes,

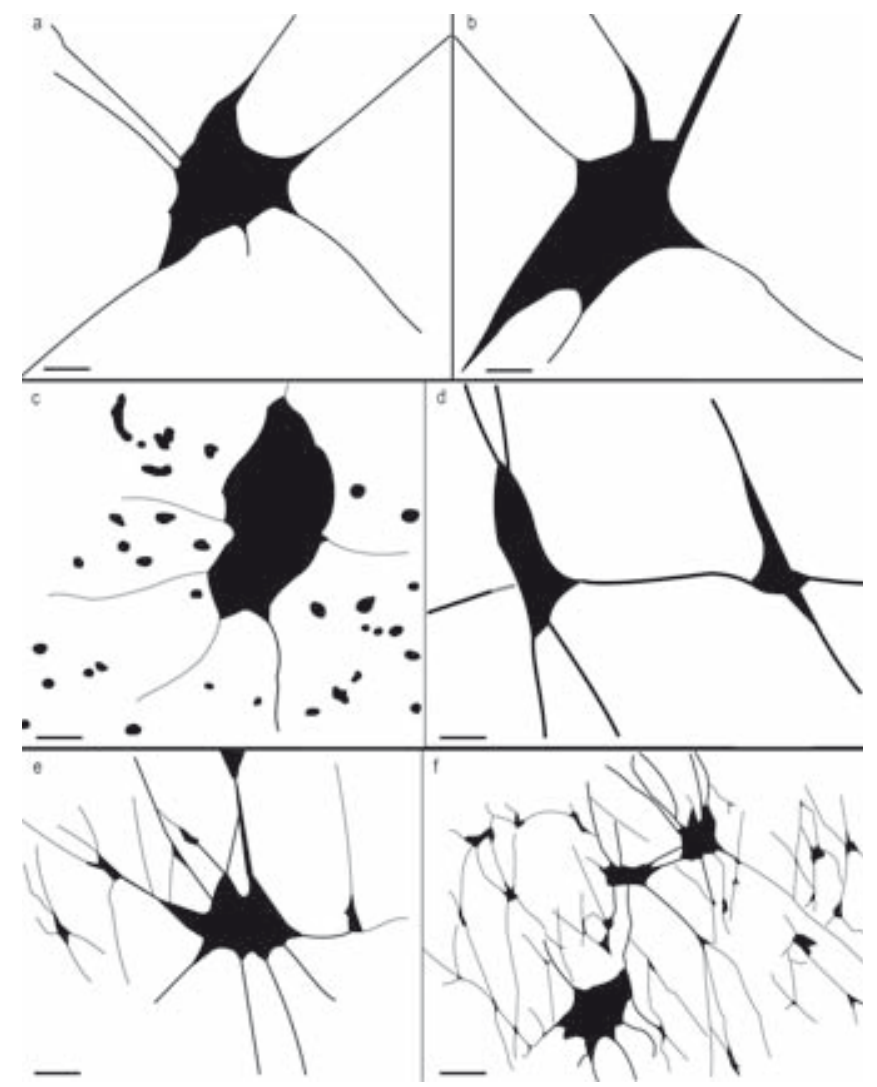

Figure 6. Sketches of large rooting structures at Bengado. a-b) With six roots, levels b and e. Section 2. c) Group of seedling imprints around a weathered large rooting, level d, Section 2. d) Connection between two simple specimens, level a, Section 1. e-f) Groups of interconnected small and larger imprints, level d, Section 2. All scale bar: $5 \mathrm{~cm}$. 

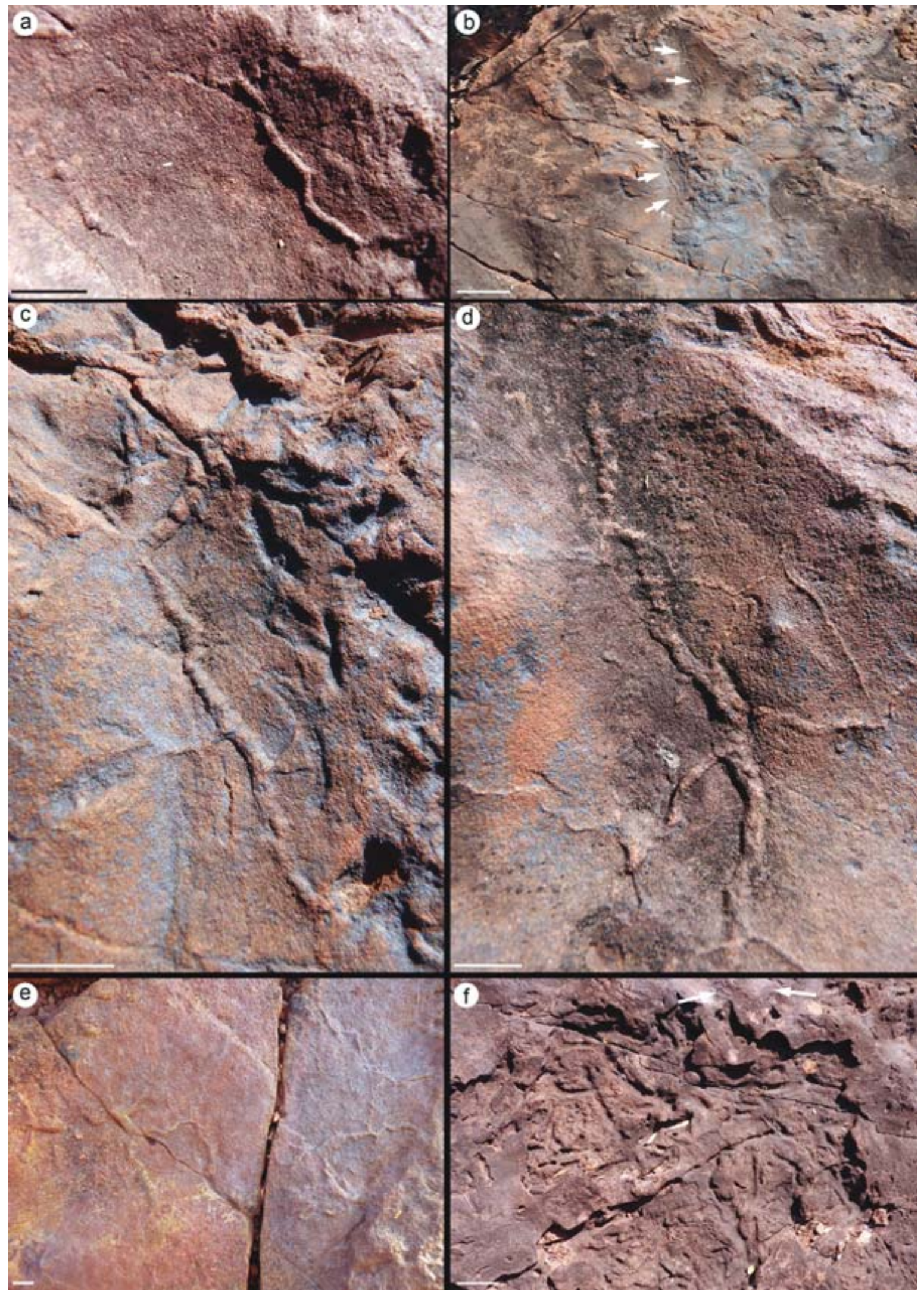

Figure 7. Trace fossils from Bengado Section 2. a) Cochlichnus angineus. Scale bar: $1 \mathrm{~cm}$. b) General view of surface with linguoid ripples showing the pathway of Vagorichnus cf. anyao (white arrows). Scale bar: $5 \mathrm{~cm}$. c-d) Close-up view of Vagorichnus cf. anyao showing the typical curved discontinuous segments and the presence of annulations concentrated in certain parts of the burrow. Scale bar: $1 \mathrm{~cm}$. e) Irregular network of Vagorichnus cf. anyao. Scale bar: $1 \mathrm{~cm}$. f) Palaeophycus tubularis preserved as concave epichnial and Vagorichnus cf. anyao (white arrows). Scale bar: $5 \mathrm{~cm}$. 

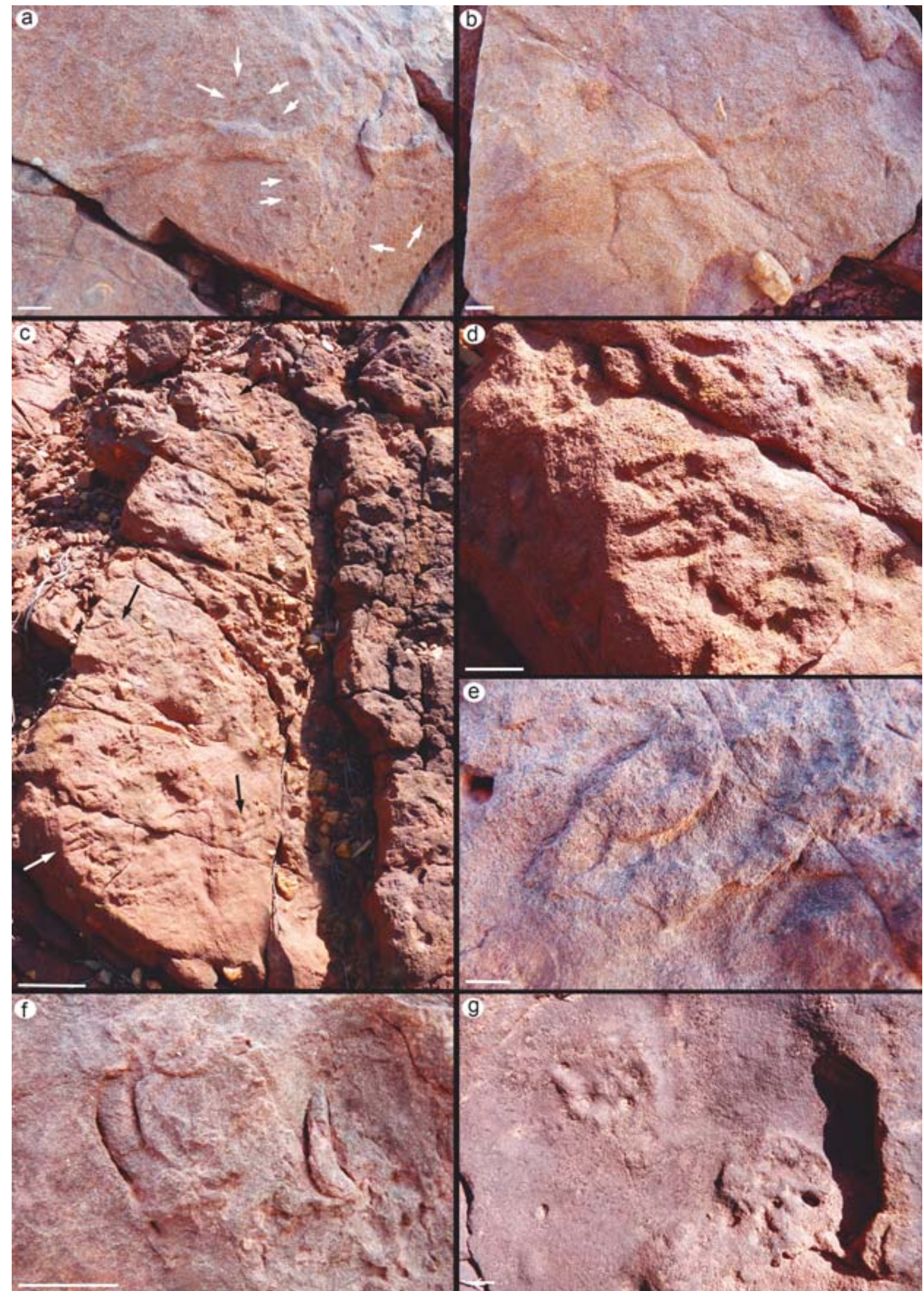

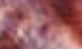

Figure 8. Trace fossils from Bengado Section 2. a) Taenidium isp. and raindrop imprints (white arrows). Scale bar: $1 \mathrm{~cm}$. b) Scolicia isp. Scale bar: $1 \mathrm{~cm}$. c-f) Rhynchosauroides isp. (c) General view of the sandstone $60 \mathrm{~cm}$ below level g, with tracks (white and black arrows). Scale bar: $10 \mathrm{~cm}$. (d) Close-up view. Scale bar: $1 \mathrm{~cm}$. (e) Close-up view of another track at level g. Scale bar: $1 \mathrm{~cm}$. (f) Idem at level i. Scale bar: $1 \mathrm{~cm}$. g) Two footprints of uncertain trace maker at level i. Scale bar: $1 \mathrm{~cm}$. 
since rooting competition for the available space was still quite tolerable.

These conditions also are deduced from frequently found smaller root imprints located around the big imprints. The much smaller ones have not yet developed the rooting system at this stage and correspond to the settlement of putative seedlings of a second generation (Figs 3g-3h, 4f, 5e, 6c). In the outcrop of section A, h level, the occupation density of these seedlings was possible to be determined, and suggests an estimated number of pits/ $\mathrm{cm}^{2}$ ranging from $90 / 200 \mathrm{~cm}^{2}$, to $57 / 2,500 \mathrm{~cm}^{2}$.

\section{INTERPRETATION}

The dark red conglomerates, sandstones and mudstones, represents the archetypical facies of these terrigenous rocks where all root impressions are found. The pebbly material in patches on the top of most sandstones suggests the deposition of density flows, while some of the more massive beds are conglomeratic. Small channel forms with cross-bedding are suggestive of shallow fluvial facies, probably braided stream deposits, although the apparent absence of these structures in some sandstones suggests that cross-bedding may have been produced only by ephemeral streams.

Moreover, the top surfaces of each flow deposit show the presence of small unsorted, angular and subangular pebbles, which were transported on top of the sandstone slurries, probably as a result of buoyancy. Such deposits may be attributed to the mobilization of weathered sandy material with angular pebbles at periods of seasonal rainfall producing flash floods. Sandstone beds were produced when dense flows became a little more fluid, producing local cross-stratification and simulating braided stream deposits.

Intervals 1 and 1-2 of series A and B from Vale das Mealhas may be considered to be lateral facies equivalent. Predominant mudstones show intercalations of lenticular sandstone and conglomerate bodies, varying from mass flow to minor stream deposits.

Intervals 2-3 and 3 of Bengado (sections 1 and 2 respectively) exhibit the best record of the imprint of rooting bases, but abundant trace fossils are present as well. Ichnofossils are found in fine-grained river overbank deposits (fine-grained sandstones) interbedded with undisturbed, coarser-grained stacked channel deposits (coarser sandstones and conglomerates). Overfilled overbank deposits contain locomotion trails (Cochlichnus angineus), horizontal dwelling burrows (Palaeophycus tubularis) and subordinate elements such as bilobate structures (Scolicia isp.), meniscate trace fossils (Taenidium isp.) and tetrapod trackways (Rhynchosauroides isp.). It is worth emphasizing the presence of these lacertoid feet morphologies, of which the trace maker was probably a small, un-derived reptile, such as a sphenodontian (Hunt \& Lucas, 2006) or, more likely, a lepidosauromorph (Haubold, 1971a, b; Klein et al., 2006).

In addition, surfaces with linguoid ripples also show raindrop imprints with two small ichnites of tetrapods and Vagorichnus cf. anyao, the latter is interpreted as an invertebrate feeding structure (fodinichnia) as found in lacustrine turbidites from the Lower Jurassic of Henan Province (China) (Buatois et al., 1995; Hu et al., 2014) and the lower Miocene of Turkey (Uchman et al., 2007). Potential tracemakers could be Annelida (Oligochaetes) and/or Arthropoda (amphipods and isopods).

In the former fluvial environment, the general succession could be the establishment of floodplain water bodies with poorly defined trace fossils followed by an incipient dewatering process giving rise, occasionally, to desiccated overbank deposits causing periodic subaerial exposure. Rooting structures, shallow vertebrate and invertebrate trace fossils and raindrop imprints would correspond to such times, when colonization by Pleuromeia-like plants would take place. These would occupy the wettest areas together with the driest around the former shallow water bodies. These marshy conditions probably favoured plant development between wet (occasional flash floods) and drier episodes. This alternation between wet and drier episodes might be the cause of a proliferation of plants, as well as their eventual destruction. In this humid environment plant development should be very fast. Flash floods, often accompanied by mass flow, may have been the cause of uprooting of plants, separating them from their rooting bases. The same events may be the cause of seedling devastation that left their imprints in several places, where they were grouped into real plant nurseries around the main, first-generation plants.

\section{CONCLUSIONS}

Imprints of rooting bases of small trees belonging to the class Lycopsida in the Silves Sandstone, Upper Triassic, eastern Algarve region (South Portugal) are described for the first time from this area. The Silves Sandstone is represented by the typical dark red conglomerates, sandstones and mudstones of the formation; this contains all the studied imprints. These have a quadrate or pseudohexagonal outline due to the emission of very narrow, usually undivided roots, placed at four to sixeight roughly symmetrical points around the stem base. Two generations of plants including seedling imprints are observed, although in general, their size can be considered small, with a distance between the trees quite small also. 
Palaeoenvironmental conditions correspond to a fluvial environment, with the establishment of a floodplain with periodic subaerial exposure; this corresponds to rooting structures, shallow vertebrate (Rhynchosauroides isp.) tetrapod footprints, invertebrate trace fossils (Cochlichnus anguineus, Vagorichnus cf. anyao, Palaeophycus tubularis, Taenidium isp., Scolicia isp.), and raindrop imprints. Lycopsids plants would colonize marshy areas generated in between humid and drier episodes. Occasional flash flood and mass flow, may be regarded as the cause of uprooting of small trees and the destruction of seedlings.

\section{ACKNOWLEDGEMENTS}

Financial support was received by the Junta de Andalucía (Spanish Government) to the Research Group RNM276 (Applied Geosciences and Environmental Engineering) of the University of Huelva, Spain. The authors are grateful to Ronny Rößler (Natural History Museum of Chemnitz, Germany) and Francisco Javier Rodríguez Tovar (University of Granada, Spain) for helpful and constructive comments, which much improved the manuscript, as well as to Carmen Álvarez-Vázquez (editor) for her careful review.

\section{REFERENCES}

Antunes, M.T. 2010. Aspectos paleontológicos de unidades não marinhas. I - Triásico do Algarve. In: Ciências geológicas: ensino, investigação e sua história. (coords. Neiva, J.M.C., Ribeiro, A., Mendes Victor, L., Noronha, F. \& Ramalho, M.M.). Vol I - Geologia clássica, Associação Portuguesa de Geólogos e Sociedade Geológica de Portugal, 315-316.

Buatois, L.A., Mángano, M.G., Xiantao, W. \& Guocheng, Z. 1995. Vagorichnus, a new ichnogenus for feeding burrow systems and its occurrence as discrete and compound ichnotaxa in Jurassic lacustrine turbidites of Central China. Ichnos, 3, 265-272; doi:10.1080/10420949509386396.

Choffat, P. 1887. Recherches sur les terrains secondaires au Sud du Sado. Comissão Trabalho Geología, Portugal, Lisboa, I/II, 22-312.

Cleal, C.J., Uhl, D., Cascales-Miñana, B., Thomas, B.A., Bashforth, A.R., King, S.C. \& Zodrow, E.L. 2012. Plant biodiversity changes in Carboniferous tropical wetlands. Earth Science Reviews, 114, 124-155; doi:10.1016/j. earscirev.2012.05.004.

Defretin S. 1950. Sur quelques Estheria du Trias français à facies germanique et de l'Hettangien. Annales de la Société Géologique du Nord, 70, 214-227.
Gall, J.C., Grauvogel-Stamm, L., Nel, A. \& Papier, F. 1998. La crise biologique du Permien et la renaissance triasique. Comptes Rendus Académie des Sciences, Paris, 326, 1-12.

Grauvogel-Stamm, L. 1998. The pioneering plants from the Buntsandstein of the German Basin. Hallesches Jahrbuch für Geowissenschaften, Reihe B: Geologie, Palaeontologie, Mineralogie, 5, 60. Epicontinental Triassic International Symposium, Halle, 1998.

Grauvogel-Stamm, L. 1999. Pleuromeia sternbergii (Münster) Corda, eine charak-teristische Pflanze des deutschen Buntsandsteins. In: Trias: Eine ganz andere Welt Mitteleuropa im frühen Erdmittelalter (eds. Hauschke, N. \& Wilde, V.). Verlag Dr. Friedrich Pfeil, München, 271-282.

Grauvogel-Stamm, L. \& Lugardon, B. 2001. The Triassic Lycopsids Pleuromeia and Annalepis: Relationships, Evolution, and Origin. American Fern Journal, 91 (3), 115-149; doi:10.1640/0002-8444(2001)091[0115:TTLP $\mathrm{AA}] 2.0 . \mathrm{CO} ; 2$.

Greb, S.F., DiMichele, W.A. \& Gastaldo, R.A. 2006. Evolution and importance of wetland in Earth history. In: Wetlands through time (eds. Greb, S.F. \& DiMichele, W.A.). Geological Society of America, Special Paper, 399, 1-40; doi:10.113072006.2399(1).

Haubold, H. 1971a. Die Tetrapodenfährten des Buntsandsteins. Paläontologische Abhandlungen A, 4, 395-548.

Haubold, H. 1971b. Ichnia Amphibiorum et Reptiliorum fossilium. Encyclopedia of Paleoherpetology, 18, 1-124.

Hermann, E., Hochuli, P.A., Bucher, H., Brühwiler, T., Hautmann, M., Ware, D., Weissert, H., Roohi, G., Yaseen, A. \& Rehman, K. 2012. Climatic oscillations at the onset of the Mesozoic inferred from palynological records from the North Indian Margin. Journal of the Geological Society, London, 169, 227-237; doi:10.1144/001676492010-130.

Hu, B., Wang, Y-Y. \& Song, H.B. 2014. The ichnofacies and ichnoassemblages in terrestrial deposits of China. Journal of Palaeogeography, 3, 61-73; doi:10.3724/ SP.J.1261.2014.00003.

Hunt, A.P. \& Lucas, S.G. 2006. Triassic-Jurassic tetrapod ichnofacies. In: The Triassic-Jurassic Terrestrial Transition (eds. Harris, J.D., Lucas, S.G., Spielmann, J.A., Lockley, M.G., Milner, A.R.C. \& Kirkland, J.I.). New Mexico Museum of Natural History and Science Bulletin, 37, 12-22.

Jenkyns, H.C. 2003. Evidence for rapid climate change in the Mesozoic-Palaeogene greenhouse world. Philosophical Transactions of the Royal Society of London, A361, 18851916; doi:10.1098/rsta.2003.1240.

Klein, H., Lucas, S.G. \& Haubold, H. 2006. Tetrapod track assemblage of the Redonda Formation (Upper Triassic, Chinle Group) in East-Central New Mexico-Re-Evaluation of ichnofaunal diversity from studies of new material. In: The Triassic-Jurassic Terrestrial Transition (eds. Harris, J.D., Lucas, S.G., Spielmann, J.A., Lockley, M.G., Milner, A.R.C. \& Kirkland, J.I.). New Mexico Museum of Natural History and Science Bulletin, 37, 241-250. 
Lopes, F. 2014. Novas interpretações do Triásico da parte central da Bacia do Algarve (Portugal). Comunicações Geológicas, 101, Especial I, 475-479.

Menning, M. 1995. A Numerical Time Scale for the Permian and Triassic Periods: An Integrated Time Analysis. In: The Permian of Northern Pangea. Vol 1. Paleogeography, Paleoclimates, Stratigraphy (eds. Scholle, P.A., Peryt, T.M. \& Ulmer-Scholle, D.S.). Springer, Berlin, 77-97; doi:10.1007/978-3-642-78593-1_6.

Moisan, Ph. \& Voigt, S. 2013. Lycopsids from the Madygen Lagerstätte (Middle to Late Triassic, Kyrgyzstan, Central Asia). Review of Palaeobotany and Palynology, 192, 4264; doi:10.1016/j.revpalbo.2012.12.003.

Palain, C. 1975. Une série détritique terrigène. Les «Grès de Silves": Trias et Lias inférieur du Portugal. Thèse d'Etat, Université de Nancy, Nancy, 1-503.

Palain, C. 1979. Connaissances stratigraphiques sur la base du Mésozoïque portugais. Ciências da Terra, 5, 11-28.

Rocha, R. 1976. Estudo estratigráfico e paleontológico do Jurássico do Algarve ocidental. Ciências da Terra, 2, 1-178.

Sellwood, B.W. \& Valdes, P.J. 2007. Mesozoic climates. In: Marrying the Signal from Computer Models and
Biological Proxies (eds. Williams, M., Haywood, A.M. Gregory, F.J. \& Schmidt, D.N.). The Micropaleontological Society Special Publications, The Geological Society, London, 201-224.

Uchman, A., Nemec, W., Ilgar, A. \& Messina, C. 2007. Lacustrine trace fossils and environmental conditions in the Early Miocene Ermenek Basin, southern Turkey. Annales Societatis Geologorum Poloniae, 77, 123-139.

Wagner, R.H. \& Diez, J.B. 2007. Verdeña (Spain): Life and death of a Carboniferous forest community. Comptes Rendus Palevol, 6 (6-7), 495-504; doi:10.1016/j. crpv.2007.09.021.

Wagner, R.H. \& Mayoral, E. 2007. The early Permian of Valdeviar in Sevilla province, SW Spain: basin history and climatic/palaeogeographic implications. Journal of Iberian Geology, 33, 93-124.

Willis, K.J. \& McElwain, J.C. 2002. The Evolution of Plants. Oxford University Press, 1-378.

Zieten, C.H. von 1833. Die Versteinerungen Württembergs. Stuttgart (Zusammengestellt von C.H. Zieten), 1-453. 
